\title{
Sanchi: Before today (In light of Nagauri quarry and factory site)
}

Sachin Kr. Tiwary ${ }^{1}$ and Rusav Kr. Sahu ${ }^{2}$

${ }^{1}$ Assist. Archaeologist, Archaeological Survey of India, J. C. Road, Anta ghat, Patna-800001, Bihar

${ }^{2}$ Research scholar, Archaeology Department, Utkal University, Bhuwaneshwar, Odisa

\begin{abstract}
The present paper deals with result obtained from recently conducted archaeological investigations in Kakanaya bill and Nagauri bill. The paper is a report of the archaeological exploration and scientific documentation of the Kakanaya bill and Nagauri bill. This study aims at presenting holistic understanding of the origin and development of the artistic activities in the region and to give the general information about the archaeological sites in the study area. The documented man activities will also discussed in detail. The present paper based on new interpretation regarding its importance for the development of Buddhist architecture and its cotemporary technique.
\end{abstract}

Key words: KARARI, NAGAURI, POST HOLE, MASSON MARK, MONOLITHIC PILLAR, ENGRAVING, QUARRY.

\section{Resumen}

El presente trabajo aborda los resultados obtenidos recientemente en las investigaciones arqueológicas llevadas a cabo en las colinas de Kakanaya y Nagauri. El articulo recoge los resultados más importantes de la exploración arqueológica y documentación científica practicada sobre las colinas Kakanaya y Nagauri. Este estudio tiene como objetivo presentar una visión holistica del origen y desarrollo de las actividades artísticas de la región, dando una información general de los sitios arqueológicos en el área objeto del estudio. Las actividades humanas documentadas en la zona también se discuten en detalle. El presente documento ofrece una nueva interpretación sobre la importancia del desarrollo de la arquitectura budista y sus técnicas contemporáneas.

Palabras clave: KARARI, NAGAURI, AGUJERO DE POSTE, MARCA MASSON, PILAR MONOLÍTICO, GRABADO, CANTERA.

\section{Introduction}

The site is located on the left bank of the river Betwa, $800 \mathrm{mtrs}$ South-West of the Sanchi hill, Raisen district of Madhya Pradesh (fig.1).

The hillock is locally known as Karari or Nagauri hill (fig.2). A large number of stones were quarried ${ }^{14}$ from this site during the construction of stupas in Sanchi hill as evidence from debitage as well as the massion marks. The site is surrounded by plain land in east, Nagauri village in north and Piparia village in south. The discovery of Rock art (fig.3) and microliths (fig.4) in the hillock pushed by the antiquity of the site as well as the Sanchi to Mesolithic period. The site was the abode of human habitation up to the medieval period evidenced from the three stages of rock paintings Mesolithic/Neolithic, early historic followed by

\footnotetext{
${ }^{14}$ A quarry is a type of open-pit mine from
}

which rock or minerals are extracted. Quarries are generally used for extracting building materials, such as dimension stone, construction aggregate, riprap, sand, and gravel. They are often collocated with concrete and asphalt plants due to the requirement for large amounts of aggregate in those materials. The word quarry can include underground quarrying for stone, such as Bath stone. the Early Medieval period on the basic of stylistic features as well as ceramic assemblages found below the rock shelters.

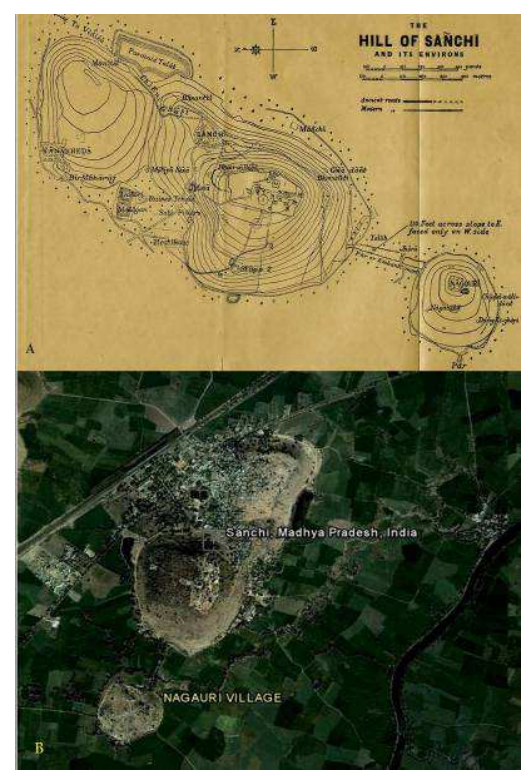

Fig. 1, Map of Madhya Pradesh showing the study area, (Courtesy: Google map) 


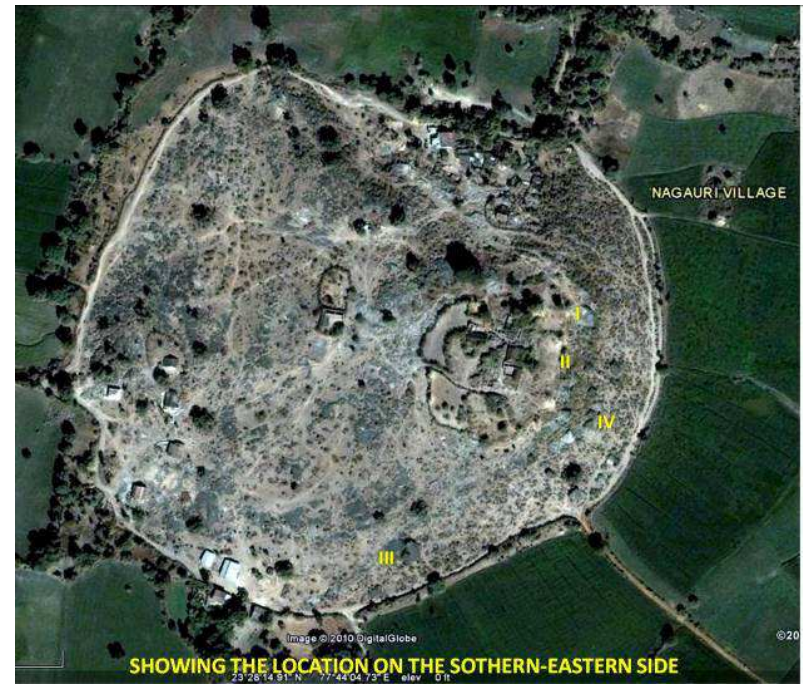

Fig. 2, Goggle map showing the vicinity of the area along with river Betwa and Sanchi Buddhist site (Courtesy: Google earth)

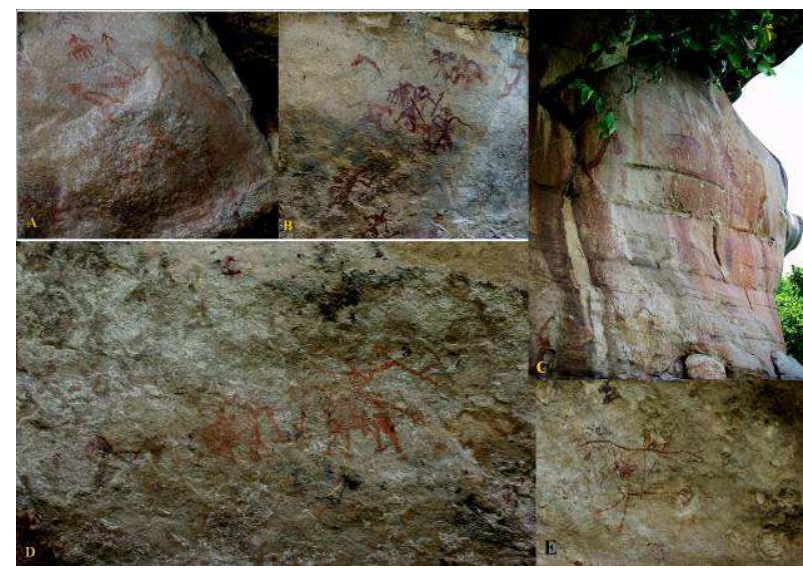

Fig. 3, Pictographs belonging to different periods, shelter no. II:

(A) pictographs belongs to Mesolithic period painted with light red colour,

B) pictographs belonging to late phase of historical period with dark red colour, warriors are in war scene along with several weapons, (C) Superimposition from Mesolithic to Historical,

(D) Pictographs belongs to historical period with light red/geru colour, warriors and elephant riders along with weapons,

(E) Unidentified light reddish coloured pictographs with dot-dot mark in one alignment,

The twin hills of Sanchi and Nagauri is separated by a depression where people used their cultivated land. The twin hillocks are surrounded by the famous Buddhist sites like Sonari and Satadhara in the north-eastern and south-eastern sides respectively. These sites were come into prominence because these were fall under the trade routes of northern and southern India. The Sanchi hill approximately measures $300 \mathrm{ft}$ in height. The site had no connection with the life and acts of Buddha. The place is scarcely mentioned in Buddhist literature and the Chinese pilgrim, Fa-Hsien and Hsuan-Tsang, tell much about other ancient centres of Buddhism but they were silent about this site. It is a strange coincidence, that these remains considered the most magnificent and perfect examples of Buddhist architecture (MARSHAL, 1955).

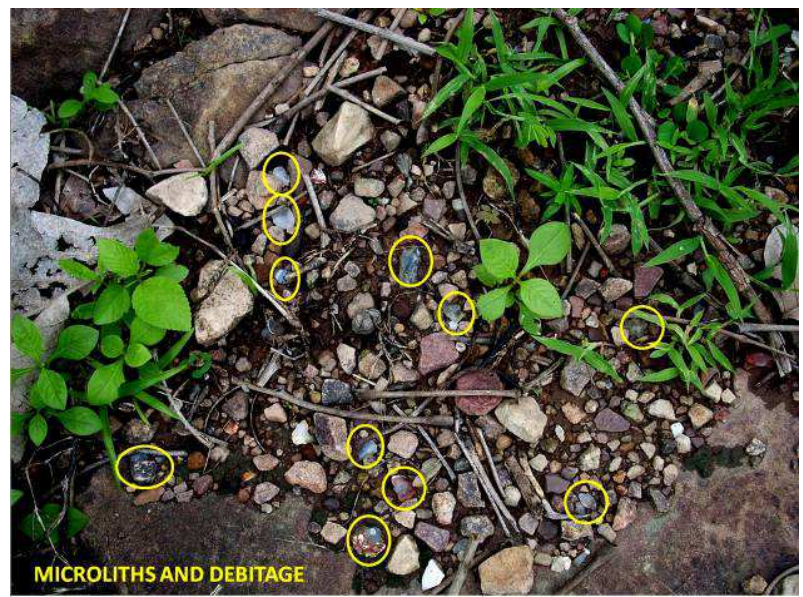

Fig. 4, The Mesolithic tools along with debitage, Nagauri hill

The site was left desolate and deserted after $13^{\text {th }}$ century A.D. Gen. Taylor rediscovered the site in 1818, proved to be remarkably in a good state of preservation. At that time three of the gateways of the Great stupa were still standing erect, and the southern one was lying where it had fallen, the great dome was intact and a portion of the balustrade on the summit was still in situ. (BURGESS, 1902)

The earliest reference to Sanchi comes from Fergusson's (FERGUSSON, 1873) Tree and Serpent Worship and Massey's (MAISEY, 1892) Sanchi and its remains. The former appeared in 1868 , treats the gateway reliefs mainly as illustrations of primitive tree and serpent worship. The latter was published in 1892, where the fanciful theories are present, that Asoka was much latter than king Piyadasi of the edicts, that Buddhism in India was approximately coeval with Christianity, and that in essence it was largely Mithraic.

Thereafter a host of scholars worked in the various aspects of Sanchi and its surrounding monuments. But nobody make an attempt to show how the gigantic monuments of Sanchi come up. From which place, the building materials had been quarried. Hence, the present paper makes a holistic approach to show, the famous Buddhist monument stands may be because of the Nagauri hill. So while discussing the Nagauri hill we have to discuss the historical and archaeological importance of Sanchi hill. Both are integrally related like the chunar sandstone and Asokan pillar. The Mauryan pillar would not be conceived without the prior importance of the chunar stone quarried from the hillock in Mirzapur district of Uttar Pradesh.

With this background, the scholars tried to attempt to discuss how the site Nagauri was responsible for the growth and development of the Buddhist edifices of Sanchi anciently known as Kakanava or kakanaya hill.

In the ancient Indian collections of stone sculpture, an image, which belongs to a particular region and a specific time bracket, are generally marked by uniformity as well as certain diversities. The evidence from Nagauri has unraveled complete picture of lithic exploitation and way of transportation from the hill to the Sanchi hill during ancient period. For example, the abandoned quarries suggest that suitable blocks were extracted from the sandstone beds lying usually on the top of the flat terrain of the hills. The blocks were thereafter chiseled in the quarry itself to give them cylindrical pillar and stone masonry shape resulting 
generally in thick accumulation of chiseling debris some of the undressed and half dressed blocks were also left unused.

The significance of this rediscovery was quite apparent since Nagauri sandstone was the most preferred lithic medium for building and art activities during the construction of Sanchi monumental complex.

From this, a half finished horse figure (fig.5) is found in the southern slope of the hillock in situ condition. The artist chiseled the entire figure stands on the surface of the rock. The horse figure is covered with vegetation and measures $1.62 \mathrm{mtrs}$ in height, $2.60 \mathrm{mtrs}$ in width and with a thickness of $0.28 \mathrm{mtrs}$. The site Sanchi is associated with Buddhism and the horse is intimately associated with Lord Buddha for which the artisans trying to sculpting the image here but due to the cracking of the images, they left that here with in situ condition.

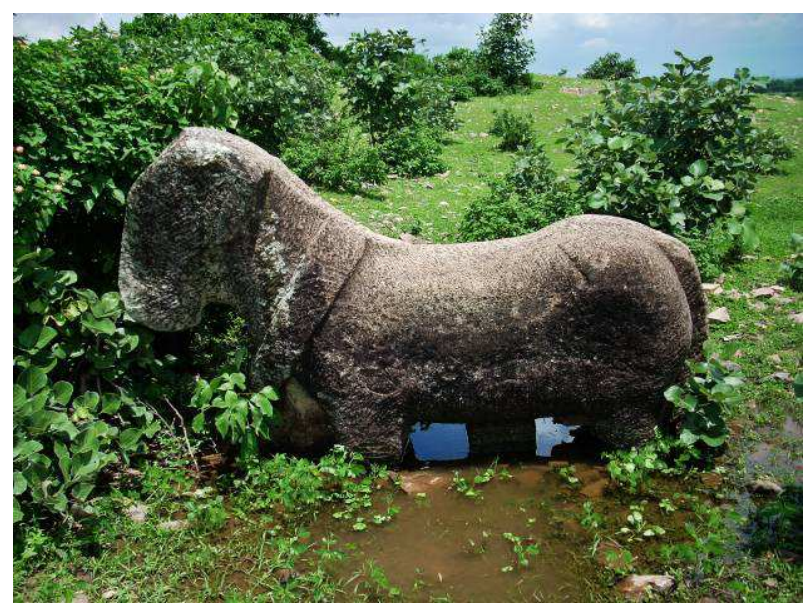

Fig. 5, The unfinished horse image

A Naga figure (fig.6) is found on the northern side of the hill crowned by a five hooded snake canopy located very close to a modern shrine. Similar type of figure is found near the stupa No-1 at Sanchi hill. Stylistically the figure ascribed to the Sunga/Satavahana period dating back to the 1 st $/ 2^{\text {nd }}$ century B.C. The sculpture is standing position and is still worshiped by the people of locality. It measures $2.10 \mathrm{mtrs}$ in height, $0.86 \mathrm{mtrs}$ in width and with a thickness of 0.52 mtrs. The image looks like a Yaksa on its body construction and right above the head seven hooded snake canopy is found. One Nagini image is found in Sanchi group of monument. Probably this image was sculpted to install their as a couple naga-nagi. Probably due to this image of Naga the hill took name Nagauri.

\section{Engraved Image}

In the western slope of the hillock, the author noticed two engraved images. Both are identified as male and female and the first one is smaller one in comparisons to female figure. The female figure measures $0.40 \mathrm{mtrs}$ in height and 0.13 in width and the male figure measures $10 \mathrm{~cm}$ in height and $4 \mathrm{~cm}$ in breadth. Similar types of images are found in the toranas of Sanchi. It can be said that these two are mother and child. Either the artisans might have experimented here or they quarried the stones and finished the images and finally they shifted the images to the Sanchi hill.

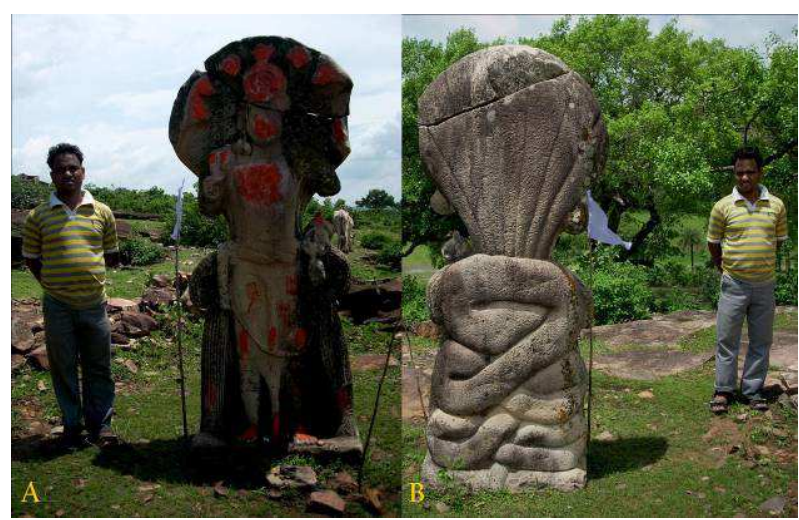

Fig. 6, Front (A) and back (B) view of broken Naga image, Nagauri bill

\section{Plan of structure}

In the same direction, just below the engraved image, the plan of a two-roomed structure has been noticed. One measures 2.75 $\mathrm{mtrs}$ in breadth and the second one measures $1.43 \mathrm{mtrs}$ in length and $2.03 \mathrm{mtrs}$ in width.

\section{Masson mark}

Through the systematic study of the masson marks (fig.7) on the surface of the rock, it can be assumed the purpose and which architectural part, the particular has been quarried. From the masson marks it indicates two groups monuments i.e. (i) Buddhist monuments like stupa and Vihara and (ii) Hindu monuments like temples. The former architectural members include Suchi, Thaba, Ushnisha and Vedika railings and the later includes amalaka and images of Hindu pantheon.

\section{Post Hole ${ }^{15}$}

The present site yielded six postholes in the eastern and western part of the hillock in two different contexts i.e. above the rock shelters and in the quarry site. The purpose is not yet clear, but it is assumed that these were used for grinding the grains. The larger one measures $0.46 \mathrm{mtrs}$ in depth with $0.26 \mathrm{mtrs}$ in diameter.

\section{Technique}

For the quarrying and removal of the blocks of stone from the bed rock they have used the metallic tools and impression over the bed rock shows their technological advancement in the second century B.C. They have used both small and big instruments for the extraction of a rock and in certain cases only small instruments has used for the removal of small pieces of

\footnotetext{
${ }^{15}$ Posthole is a cut feature used to hold a surface timber or stone. They are usually much deeper than they are wide although truncation may not make this apparent. Although the remains of the timber may survive most postholes are mainly recognizable as circular patches of darker earth when viewed in plan. Archaeologists can use their presence to plot the layout of former structures as the holes may define its corners and sides or for grinding purpose.
} 
rock. One larger stones shows the imprint of the masson mark that measures $0.18 \mathrm{mtrs}$ in height, $0.11 \mathrm{mtrs}$ in width and with a depth of $4 \mathrm{~cm}$.

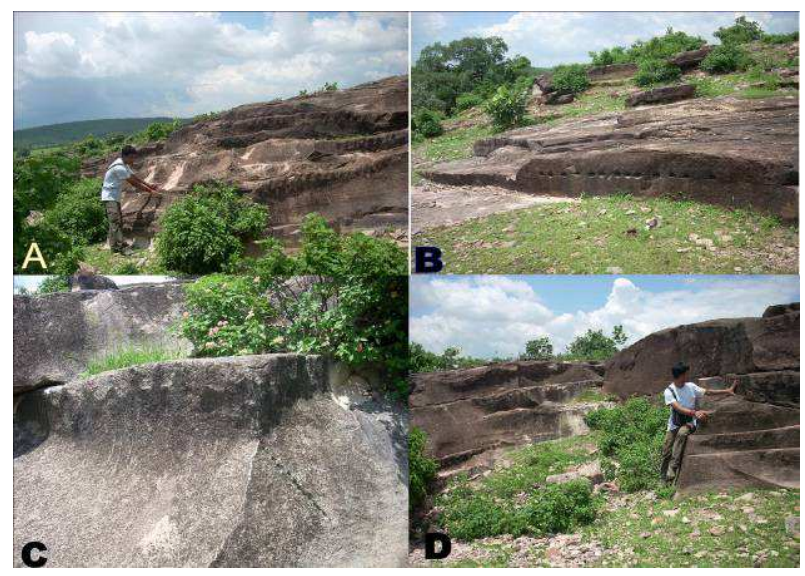

Fig. 7, The quarry marks on the Nagauri bill (from $A$ to D)

\section{Observation}

For the smoothness as well as to weakening the surface of the rock, they fired over the rock and suddenly poured the water for which the cracks have been developed. With this, they are hammering over big and small iron chisels to remove the blocks of stone. Similar types of technique also have been used in the Rathas of Mahabalipuram.

The artisans also not used any particular sharpener stone rather they have used the same bed rock for the sharpening of the metallic tools where the impressions has been left.

\section{Stone pillar}

On the way to Nagauri hill from Sanchi Museum through the slope of the Sanchi hillock the scholars noticed one big round shaped pillar which might have been used as oil machine. It measures $1.60 \mathrm{mtrs}$ in length with a diameter of $0.29 \mathrm{mtrs}$.

\section{Masson's House}

It is very interesting that the masonry work definitely takes so many years of time to complete the whole work regarding the Sanchi monument complex. So how and where they were living its matter of interesting. Though we are getting the evidence of drainage system and other water activity, still these were not used for this purpose rather for the monastic activities for the Buddhist monks.

\section{Hypothesis:}

The first presumption of the proposed hypothesis was that the hills around Nagauri were the principle resource formations, which were exploited extensively during the historical period. Archaeological investigations conducted around Nagauri during July-August revealed that the low-lying hill range near Karari or Nagauri village was the main quarry area. Nagauri was the main resource area for sandstone, which was utilized for sculpture and architecture during ancient period approximately Sanchi. Our strong believe that the quarried stones were transported from the hill through path. (Image) identification as quarries was ascertained by the marks of extraction of stone blocks, chiseling debris, undressed, half dressed art objects.

In spite of intensive survey of the site, nether the local carving of stones found in Sanchi, nor did we find any reference to the recovery of chiseling debris in the reports of the earlier investigations at Sanchi. It was thus, apparent that the sculpture making workshops under study were located away from this religious establishment.

\section{Discussion and Conclusion:}

The archaeological investigations carried out in the Nagauri, have brought to light significant evidence for the reconstruction of stone craft of the period, interpretation of some of our results could provide possible explanations to some of these enquiries. In the course of the examination of the data from Nagauri region a number of other observations were made which though not directly relevant to the theme of this article, yet were very important for the reconstruction of the cultural history of the present study area.

\section{References}

MARSHAL, J. (1955): A Guide to Sanchi, Pub. The Manager of Publications, Delhi, (3rd Edi.).

BURGESS, J. (1902): "The Great Stupas at Sanchi - Kanakheda", J.R.A.S., Jan., pp. 29-45, where a succinct account is given of the history of the site since 1818 .

FERGUSSON, J. (1873): Tree and Serpent Worship, 2nd Ed., London.

MAISEY, F.C. (1892): Sanchi and its Remains, London. 